\title{
Contaminated Irrigation Water: A Source of Human Pathogens on Growing Vegetables
}

\author{
Soodb $^{1}$, Sahotap ${ }^{1 *}$ and Hunjanm ${ }^{2}$ \\ ${ }^{1}$ Department of Microbiology, Punjab Agricultural University, Ludhiana \\ ${ }^{2}$ Department of Plant Pathology, Punjab Agricultural University, Ludhiana
}

Submission: December 05, 2017; Published: February 01, 2018

*Corresponding author: Parampal Sahota, Department of Microbiology, Punjab Agricultural University, Ludhiana-141004,

Email: parampal@pau.edu

\begin{abstract}
People are being more comprehensive to the nutritional benefits of raw vegetables and have changed their eating habits. Undoubtedly, fresh vegetables are rich in nutrients, vitamins and minerals essential for health but with a downside of both epiphytic non-pathogenic and pathogenic bacteria like Salmonella enterica and Bacillus cereus causing illness. Soils irrigated with sewage water for raising crops and a soil nearby sewage disposal sites possesses the potential pathogenic load. The faecal index of such sewage water used for agriculture was above the maximum permissible limit of $100 \mathrm{MPN} / \mathrm{ml}$ (Recommended by Indian Environment Ministry). These food pathogens are predominately found on vegetables sourced from those regions and were characterized as highly virulent due to presence of disease causing genes in them. They have high multiple drug resistance index which pose a grave threat to public health. There is need to monitor the quality of irrigation water for public health safety. Further, the vending operations should be critically controlled to decrease the risk of contamination by improper storage and handling of the vegetables.
\end{abstract}

Keywords: Agriculture; Faecal; Sewage; Fresh vegetables; Pathogen

Abbreviations: Most Probable Number (MPN)

\section{Introduction}

The reported outbreaks of gastrointestinal disease in recent years are directly linked to contamination of fresh produce like tomatoes, spinach, lettuce and seed sprouts with Enterobacteriaceae members viz. Salmonella spp., Escherichia coli 0157:H7 and Shigella spp. Other bacteria associated with the food poisoning outbreaks are Campylobacter spp. and Listeria monocytogenes [1,2]. Bacteria use plants as a vector/ vehicle for their dissemination to new areas. They tend to become dormant due to low population threshold but nutrient availability from vegetables and temperature abuse during storage soar up their threshold to the state of pathogenicity in human or animals. Bacteria manage to survive adverse environmental conditions as localize in protected niches via root internalization, stomata, or during physical or biological damage to plant organs $[3,4]$. Salmonella and Escherichia coli 0157:H7 have high survival ability on fresh herbs for at least 24 days at refrigeration temperature [5]. Horizontal transfer of resistance contributes to multiple antibiotic resistances in epiphytic as well as pathogenic microorganisms in fresh produce [6]. The survival of disease causative agent under different environmental conditions represents one of the factors which determine the spread of diseases between the consumers of contaminated water or food
[7]. Untreated sewage water is being used for crop irrigation in many developing countries. Sewage irrigated Ready-to-eat (RTE) samples drawn from Hidalgo, Mexico, harboured faecal coliforms, Escherichia coli and diarrheagenic Escherichia coli [8]. In Punjab - Buddha Nallah and its sewage polluted water is distributed throughout the Ludhiana District via irrigation canals and used for agriculture purpose. The vegetables grown in such regions are at high risk of carring the disease causing microorganisms. The surface water analysis of one of the water channels of Budha Nallah reveals high values of total dissolved solids up to $1642 \mathrm{mg} / \mathrm{L}$, chlorides up to $400 \mathrm{mg} / \mathrm{L}$, Chemical Oxygen Demand values up to $448 \mathrm{mg} / \mathrm{L}$, Biochemical Oxygen Demand 52-195 mg/L, Most Potable Number varying from 240+ upto $2400+$ per $100 \mathrm{ml}$, heavy metal like $\mathrm{Cr}$ in the Budha Nallah has value $0.031 \mathrm{mg} / \mathrm{L}, \mathrm{Fe} 0.913 \mathrm{mg} / \mathrm{L}, \mathrm{Mn} 0.043 \mathrm{mg} / \mathrm{L}$ and $\mathrm{Ni}$ $0.222 \mathrm{mg} / \mathrm{L}$ [9]. The groundwater quality, however in recent time has got deteriorated due to the percolation of polluted water along Buddha nallah. High MPN index (upto 2400) of water samples collected from adjoining regions along Buddha nallah was reported [7]. The limit of faecal coliform at 10MPN/ $\mathrm{ml}$ is desirable as recommended by Indian environment ministry with maximum permissible limit at $100 \mathrm{MPN} / \mathrm{ml}$ for discharge of treated sewage into a water body or reuse for agriculture. 
Decaying organic matter is one of the most frequent reservoirs of human pathogens that cause the contamination of growing vegetables through soil leading to the transient colonization of the human intestine. According to Bureau of Indian standards (BIS), fresh produce must be microbiologically safe for consumption, regardless of any processing or transportation. According to the report of Center for Disease Control and Prevention in 2016 [10], an outbreak related to contaminant Salmonella in cucumber was expected in America. Many researchers have found Salmonella in lettuce, spinach, tomato, radish $[1,11]$. Due to changing eating habits and increase in consumption of Continental and Chinese cuisines using indigenous vegetables, risk associated with virulent food borne pathogens is also increasing. The present study was conducted involving epidemiological surveillance of seven fresh vegetables generally consumed as raw due to their higher nutraceutical properties. Evaluation of the microbiological quality of seven fresh vegetables being grown along the Buddha Nallah, Salmonella enterica count in range of 4.32 to $5.09 \log$ cfu g-1 and Bacillus cereus count from 2.69 to $4.35 \log$ cfu g-1 was recorded in samples of carrot, radish, cucumber, tomato, cabbage, spinach and long melon $[12,13]$. Many other human pathogens were also found including E. coli, A. hydrophila, S. flexneri, L. monocytogenes, Y. enterocolitica, C. jejuni, V. cholera, K. pneumonia and S. aureus were also detected on fresh vegetables.

The source linked with the risk of contamination can be the irrigated water, improper handling, storage and transportation. The presence of bacterial pathogens in irrigated water and soil is also a cause of drug resistance among microbial community. So, constant efforts were made to evaluate the persistence of pathogens on the basis of virulence factors and antibiogram profiling involving the clustering analysis for diversity study. Certain epidemiological studies have illustrated the Multi Drug Resistant (MDR) Salmonella enterica and Bacillus cereus predominately present in fresh produce [12-15] (Annexure I, II). Resistance to antibiotics like ampicillin, Cloxacillin, Tetracycline, chloramphenicol and trimethoprim-sulfamethoxazole $[12,13,15]$ against salmonella strains has been cited which can reflect the seriousness of the drug resistance issues. The mobility of these pathogens from field to fork and their virulence expression in mammalian cells can detrimentally effect the public health and safety.

The detection of pathogens in food is always cumbersome and food related illness often go unrecognised in India. Traditional culturing methods take 4-7 days for confirmation and are not much reliable. Many molecular tools have been used now-a-days to circumvent such issues and detect the pathogens present in their minimum concentration. A PCR based detection protocol has been developed and effective remedial measures have been suggested to counter the risk of health hazards associated with fresh vegetables [16]. A rapid yet inexpensive detection technique based on the Multiplex PCR was devised in which hblD gene (430bp fragment) of B. cereus; ystA gene (79bp fragment) of Y. enterocolitica; invA gene (280bp fragment) of S. enterica and iap gene in L. monocytogenes (225bp fragment) were targeted. This approach can be used as an alternative method for the routine microbiological analysis of food samples. The high sensitivity, specificity and cost effectiveness can make this an ideal test for screening of possible contaminated food samples.

The quality of water used for irrigation of fields along Buddha nallah was assessed by drawing out the samples from the hand pumps of village fields. The results with high MPN index of $>10 \mathrm{ml}-1$ were found in $75.6-98.5 \%$ of samples for total coliforms and $59.6-91.2 \%$ for faecal coliforms [12]. This substantiates the fact that ground water is contaminated with faecal coliforms due to the percolation of sewage water of Buddha nallah. Very little attention was given to the traditional processing methods. The vending operations in the city attempting to meet the food demand of the inhabitants pose their health in risk as the street food contain human pathogens in suffice to cause a serious disease [17]. India witness many food borne illness cases due to consumption of food from street vendors $[17,18]$. Such trading practices without any hygiene interventions may help these epiphytic pathogens to flourish and reach a virulence threshold.

\section{Conclusion}

The study conducted so far for the quality of fresh produce in the village fields along Buddha nallah apparently indicates the risk of illness associated with its consumption. This further led the researchers to evident the ground water in village fields near Buddha nallah as immediate source of contamination which the plants are inheriting. The high level of BOD, COD and nutrient availability to human pathogens in sewage water can increase the threshold of their virulence. The farming practice in those regions cannot be avoided as many families rely for income on this trade only. The efforts should be made in treating the water of Buddha nallah so as to reduce the organic matter and the faecal coliform content to permissible level for agriculture use.

\section{References}

1. Oliveira MAD, D'Souza VM, Bergamini AMM, Martinis ECPD (2011) Microbiological quality of ready-to-eat minimally processed vegetables consumed in Brazil. Food Control 22: 1400-1403.

2. Oranusi S, Olorunfemi OJ (2011) Microbiological safety evaluation of street vended ready-to-eat fruits sold in Ota, Ogun state, Nigeria. International Research Journal of Biological Sciences 1(3): 27-32.

3. Sela S, Manulis-Sasson M (2015) What else can we do to mitigate contamination of fresh produce by foodborne pathogens? Microb Biotechnol 8(1): 29-31.

4. Critzer FJ, Doyle MP (2010) Microbial ecology of foodborne pathogens associated with produce. Curr Opin Biotechnol 21(2): 125-130.

5. Hsu BM, Wu SF, Huang SW, Tseng YJ, Ji DD, et al. (2010) Differentiation and identification of Shigella spp. and entero invasive Escherichia coli in environmental waters by a molecular method and biochemical test. Water Res 44(3): 949-955.

6. Falomir MP, Gozalbo D, Rico H (2010) Coliform bacteria in fresh vegetables: from cultivated lands to consumers. Current Research, 
Technology and Education Topics in Applied Microbiology and Microbial Biotechnology 2: 1175-1181.

7. Sahota P, Sharma N, Kirandip, Pandove G (2014) Occurrence of Yersinia enterocolitica in drinking water in the absence of indicator organism. World Journal of Pharmaceutical Research 3(4): 529-542.

8. Castro RJ, Cortés CJF, Méndez Reyes E, Lopez Hernandez D, Gómez Aldapa CA, Estrada Garcia T (2012) Presence of faecal coliforms, Escherichia coli and diarrheagenic E. coli pathotypes in ready-to-eat salads, from an area where crops are irrigated with untreated sewage water. Int J Food Microbiol 156(2): 176-180.

9. Singh G, Singh D, Sharma SK (2013) Effect of polluted surface water on groundwater: a case study of Budha Nallah. Journal of Mechanical and Civil Engineering 5(5): 1-8.

10. Centers for Disease Control and Prevention (2016) Multistate outbreak of Salmonella poona infections linked to imported cucumbers. Retrieved.

11. Sant'Ana AS, Barbosa M, Destro MT, Landgraf M, Franco B (2012) Growth potential of Salmonella spp. and Listeria monocytogenes in nine types of ready-to-eat vegetables stored at variable temperature Conditions during shelf-life. Int J Food Microbiol 157(1): 52-58.

12. Sood B, Sahota P, Hunjan M (2017a) Multidrug Resistant Bacillus cereus in Fresh Vegetables: A Serious Burden to Public Health. Int J Curr Microbiol App Sci 6(4): 649-661.
13. Sood B, Sahota P, Hunjan M (2017b) Fresh Farm Vegetables as a Source of Virulent Drug Resistant Salmonella Enterica. Int J Curr Microbiol App Sci6(8): 3233-3245.

14. Ochiai RL, Acosta CJ, Danovaro-Holliday MC, Baiqing D, Bhattacharya SK, et al. (2008) A study of typhoid fever in five Asian countries: disease burden and implications for controls. Bull World Health Organ 86(4): 260-268.

15. Sood S, Kapil A, Das B, Jain Y, Kabra SK (1999) Re-emergence of chloramphenicol-sensitive Salmonella typhi. Lancet 353(9160): 12411242.

16. Sood B, Sahota P, Hunjan M (2016) National Conference on Technologies in Sustainable Food Systems (TSFS-2016) entitled "Plants as Carriers of Human Pathogenic Bacteria-- Risk Assessment. Detection and Decontamination", India.

17. Estrada-Garcia T, Lopez-Sancedo C, Zamarripa AB, Thompson MR, Gutierrez L (2004) Prevalence of Escherichia coli and Salmonella spp. in street vended food of open markets (tianguis) and general hygienic and trading practices in Mexico City. Epidemiol Infect 132(6): 11811184.

18. Chumber SK, Kaushik K, Savy S (2007) Bacteriological analysis of street foods in Pune. Indian J Public Health 51(2): 114-116.

19. Ghosh M, Wahi S, Ganguli KM (2007) Prevalence of enterotoxigenic Staphylococcus aureus and Shigella spp. in some raw street vended Indian foods. Int J Environ Health Res 17(2): 151-156.

Your next submission with Juniper Publishers
will reach you the below assets
- Quality Editorial service
- Swift Peer Review
- Reprints availability
- E-prints Service
- Manuscript Podcast for convenient understanding
- Global attainment for your research
- Manuscript accessibility in different formats
( Pdf, E-pub, Full Text, Audio)
- Unceasing customer service
Track the below URL for one-step submission
https://juniperpublishers.com/online-submission.php

